\title{
Prevalence and seasonal variation in ticks on Muscardinus avellanarius from Germany (Rodentia: Gliridae)
}

\author{
Prevalence a sezonní proměnlivost klíšt’at na plšíku lískovém \\ (Muscardinus avellanarius) v Německu (Rodentia: Gliridae)
}

\author{
Johannes LANG ${ }^{1,2}$, Sarah BEER ${ }^{1}$, Nicolle BRÄSEL ${ }^{1}$, Ines LEONHARDT ${ }^{1}$ \\ \& Sven BÜCHNER ${ }^{3}$ \\ ${ }^{1}$ Institute for Animal Ecology and Nature Education, Hauptstraße 30, D-35321 Laubach, Germany \\ ${ }^{2}$ Clinic for Birds, Reptiles, Amphibians and Fish, Working group for Wildlife Biology, \\ Justus-Liebig-University Giessen, Frankfurter Straße 91-93, D-35392 Giessen, Germany; \\ johannes.lang@vetmed.uni-giessen.de \\ ${ }^{3}$ Ortsstraße 174, D-02829 Markersdorf, Germany
}

received on 12 June 2018

\begin{abstract}
We sampled ticks infesting hazel dormice (Muscardinus avellanarius) between May 2017 and September 2017 at seven locations in Germany. Of a total of 221 dormice examined, 19\% were infested by ticks, but the prevalence of infestation varied strongly between sites and months. The highest prevalence at one site was noted in September (55\%) while the lowest was in July (0\%). In June, prevalence differed between sites from $0 \%$ to $47 \%$. Most frequently, dormice were infested by one tick. The maximum number of ticks found on one animal was 12. All ticks were detected on the head of the animals, where the most common feeding sites were ears, nose and the area around the eyes.
\end{abstract}

Key words. Hazel dormouse, ectoparasites, Ixodes ricinus, parasites, mammal host.

\section{INTRODUCTION}

Parasites live in or on hosts from which they derive resources for their own growth, survival and reproduction (PRICE 1980). Although restricted to the host's first line of defence against environmental conditions (the integument, away from vital organs), ectoparasites can have a pronounced impact on their host's fitness (LEHMANN 1993). They can for example increase the metabolic rate (KHOKHLOVA et al. 2006), slow the rate of growth (VAN VUREN 1996), decrease litter size (NeuHaus 2003), enhance morbidity (PFÄFfle et al. 2009) and reduce survival (LeHMANN 1992, VAN VUREN 1996) of their mammalian hosts.

Ectoparasite infestation is not only relevant for the host itself. In some cases, hosts can play a significant role in enzootic cycles of ectoparasite-borne pathogens. For example, small rodents serve as important reservoir hosts for the spirochaetes that cause tick-borne Lyme disease. In Central Europe, hazel dormice (Muscardinus avellanarius), garden dormice (Eliomys quercinus) and edible dormice (Glis glis) seem to support this pathogen more efficiently than do mice or

This contribution has been presented at the 10th International Dormouse Conference held at the University of Liège, Belgium, on 11-15 September 2017 
Table 1. Numbers of hazel dormice examined for ticks at different sites and during different months Tab. 1. Počty plšíků lískových vyšetřených na př́tomnost klíštaat na různých lokalitách a v různých obdobích roku

\begin{tabular}{llccc}
\hline $\begin{array}{l}\text { site number / } \\
\text { číslo lokality }\end{array}$ & $\begin{array}{l}\text { site name } \\
\text { / lokalita }\end{array}$ & $\begin{array}{c}\text { federal state / } \\
\text { spolková země }\end{array}$ & $\begin{array}{c}\text { number of dormice examined } \\
\text { / počet vyšetřených plšíků }\end{array}$ & $\begin{array}{c}\text { month/s / } \\
\text { měsíc/e }\end{array}$ \\
\hline 1 & Highway A44 & Hesse / Hesensko & 175 & V-IX \\
2 & Affoldern & Hesse / Hesensko & 5 & VI \\
3 & Braunau & Hesse / Hesensko & 5 & VI \\
4 & Graburg & Hesse / Hesensko & 17 & VI \\
5 & Hainleite & Thuringia / Duryňsko & 5 & VI \\
6 & Rhön & Thuringia / Duryňsko & 9 & VI \\
7 & Spitzberg & Saxony / Sasko & 5 & VI \\
\hline
\end{tabular}

voles (RICHTER \& MATUSCHKA 2012). Reservoir competence and the number of ticks feeding on a host are crucial variables determining the prevalence of infection in the rodent and tick populations.

As part of a long-term study on tick infestation of hazel dormice, we investigated the prevalence of tick infestation at different sites and in one site during the whole season of activity of these dormice. We also recorded the most common feeding sites for ticks on the dormouse body.

\section{MATERIAL AND METHODS}

We sampled ticks infesting hazel dormice between May and September 2017 at seven different locations in Germany (Table 1). Dormice were examined in the course of checking nest boxes and nest tubes for regular monitoring projects (BüCHNER et al. 2010) and during mitigation measures (LANG et al. 2018). Six sites were sampled only in June, whereas site 1 at highway A44 was sampled every two weeks. Every dormouse encountered was weighed, aged and sexed, except for juveniles $<10 \mathrm{~g}$, and carefully examined for ticks. Numbers of ticks found may be underestimated because larval ticks during their early feeding may have gone undetected. Even though larval and nymphal ticks can easily be distinguished by the number of legs, developmental stages were not determined in order to minimise handling time of the dormice. Whenever possible, ticks were carefully removed and stored for further examination.

\section{RESULTS}

A total of 221 hazel dormice were examined and 125 ticks were found on 41 of them. The overall prevalence of tick infestation in hazel dormice was $19 \%$, varying strongly between sites and months (Figs. 1 and 2). In June, their occurrence differed between sites from $0 \%$ to $47 \%$ (Fig. 1). At the site where nest boxes and nest tubes were checked every two weeks (site 1 in Table 1), the highest occurrence $(55 \%)$ was reported in September while the lowest $(0 \%)$ was found in July (Fig. 2). Most frequently, dormice were infested by one tick (Fig. 3). The maximum number of ticks found on one animal was 12. All ticks detected were feeding on the head of the animal. The most common feeding sites were ears, nose and the area around the eyes (Fig. 4). First examination of the ticks collected revealed that the majority were Ixodes ricinus. Other tick species have not yet been determined to species level. 


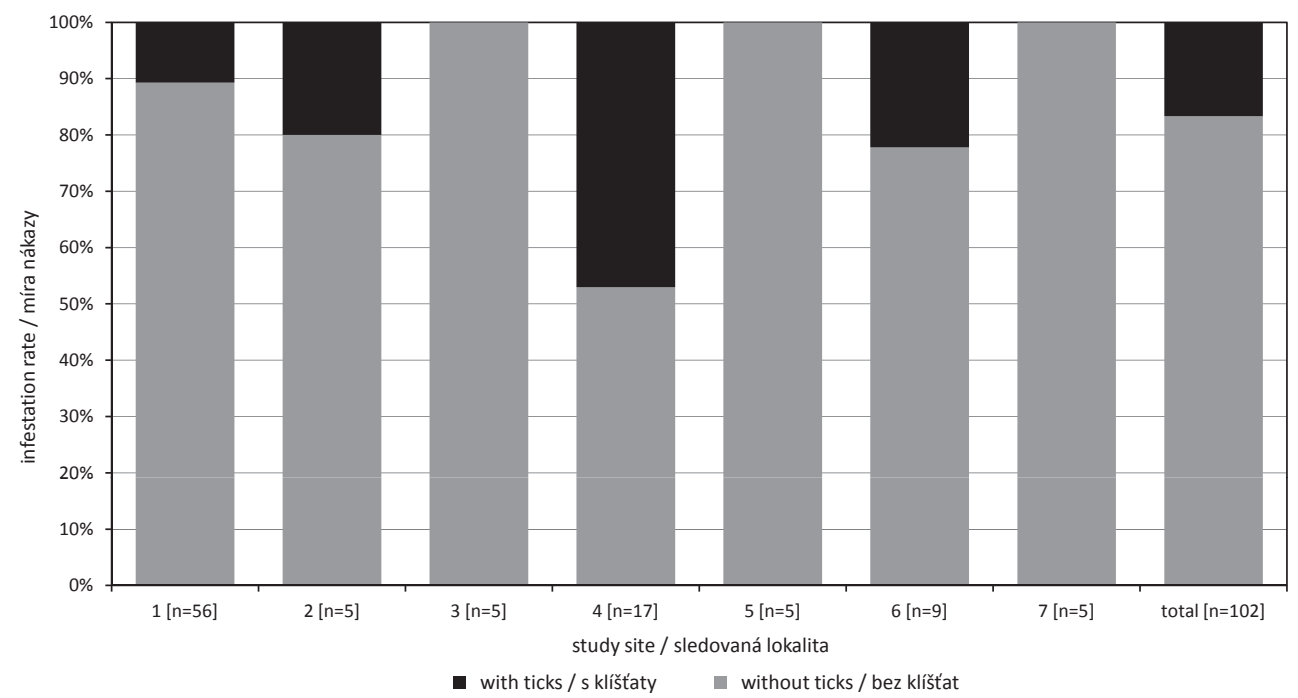

Fig. 1. Prevalence of infestation of hazel dormice with ticks in June 2017 at seven sites in Germany. Obr. 1. Prevalence nákazy plšíků lískových klíšt’aty v červnu 2017 na sedmi lokalitách v Německu.

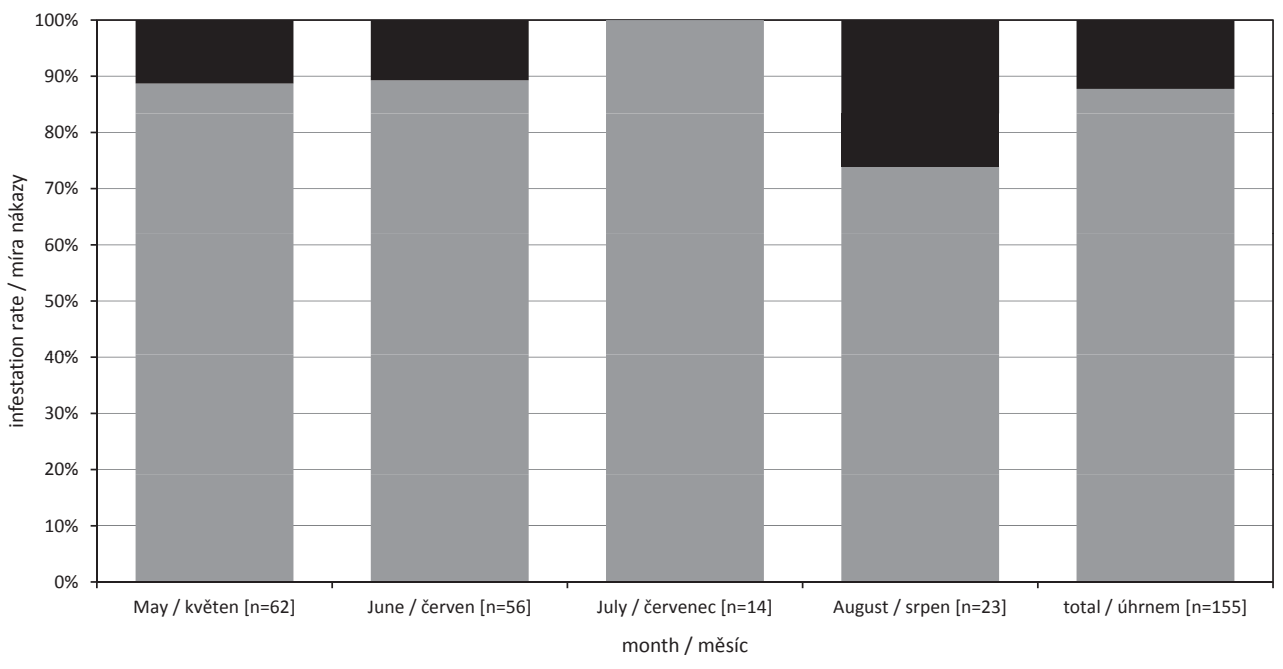

- with ticks / s klíštaty without ticks / bez klištat

Fig. 2. Monthly prevalence of infestation of hazel dormice with ticks between May and September 2017 at site 1 at highway A 44 (the federal state of Hesse, Germany).

Obr. 2. Měsíční prevalence nákazy plšíků lískových klišstaty mezi květnem a záŕím 2017 na lokalitě 1 u dálnice A44 (spolková země Hesensko, Německo). 


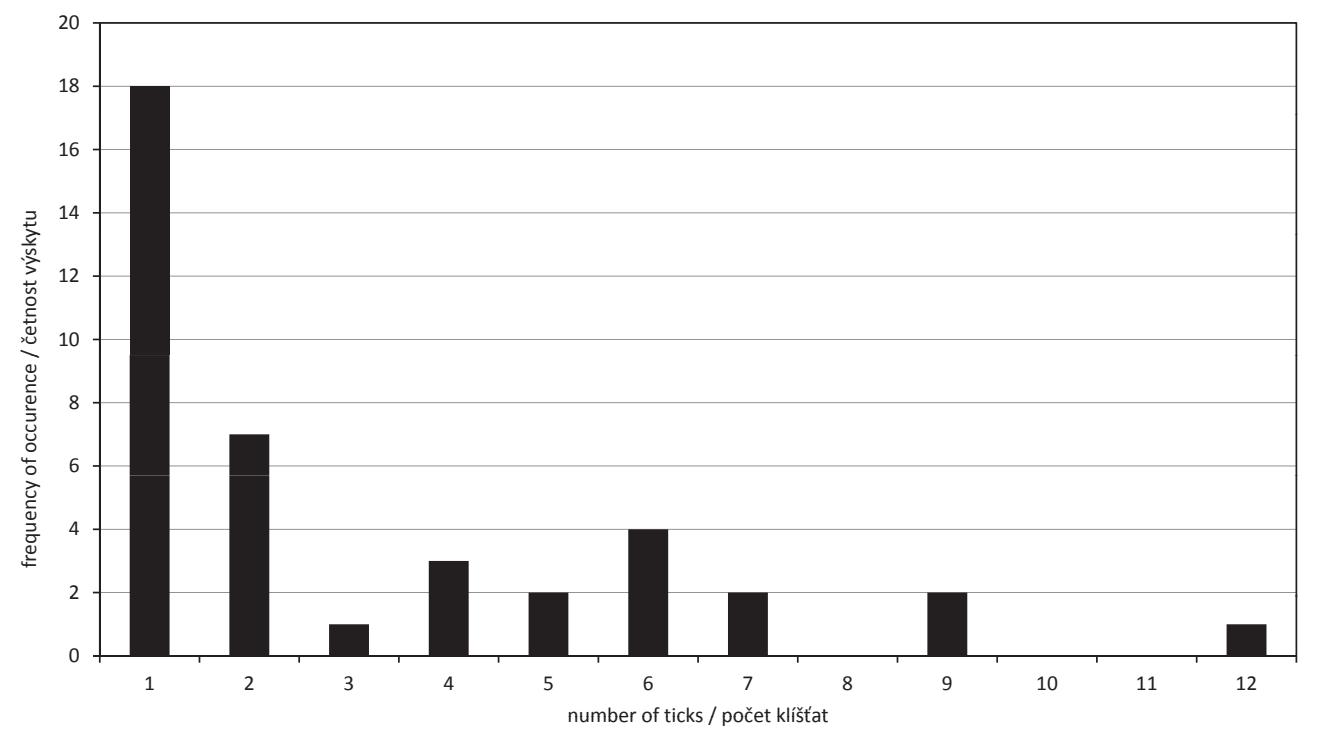

Fig. 3. Frequency of tick numbers on tick-infested hazel dormice in Germany. Obr. 3. Početnost klíšt’at na klíšt’aty nakažených plšících lískových v Německu.

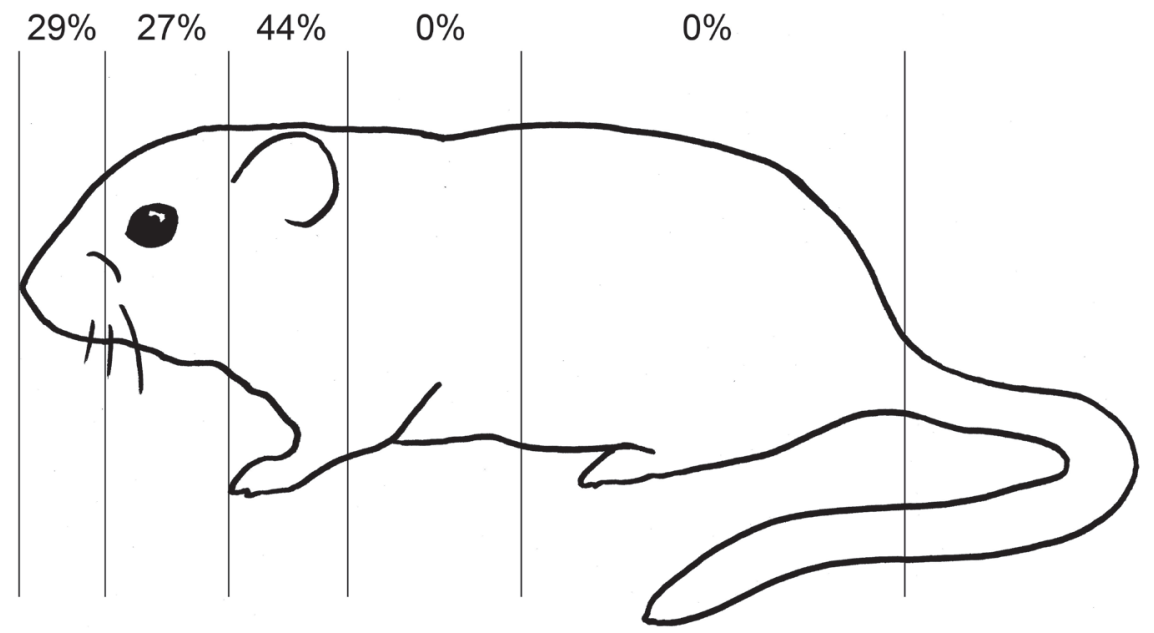

Fig. 4. Relative abundance of ticks feeding at specific sites on the hazel dormouse body. Obr. 4. Relativní hojnost klišt’at sajících na určitých místech těla plšíka lískového. 


\section{DISCUSSION}

Data on ectoparasites of the hazel dormouse are comparatively scarce but it is well known that they carry, at least occasionally, fleas, mites and ticks (JUŠKAITIS \& BüCHNER 2013). Ticks have been found frequently on hazel dormice from Belgium, France, Germany and Lithuania (RicHTER et al. 2004, JušKaitis \& Büchner 2013, JušKaitis 2014, G. Verbeylen pers. comm.). The majority of ticks feeding on hazel dormice, as for other rodents, were immature stages (CULL et al. 2017). Ixodes ricinus, frequently found in this study, is the most common tick in Central Europe and is the primary vector of many pathogens (ALKISHE et al. 2017).

As ticks feed on their host for a few days, overall as well as seasonal prevalence of infestation depend on the frequency of encounters. The overall prevalence we recorded on hazel dormice is lower than found on most ground-dwelling rodents and on other dormice (MATUSCHKA et al. 1999, Richter \& Matuschka 2012, Fietz et al. 2016, Cull et al. 2017 and references therein). The fact that the prevalence of infestation was considerably lower in July may result from climatic differences. Ticks live lower on vegetation during dry and warm weather when the risk for them of desiccation is high (RANDOlPh \& Storey 1999, PÉRez et al. 2012). Arboreal rodents, such as hazel dormice, usually live in shrubs or trees and avoid moving on the ground (BRIGHT \& MoRris 1991, 1992). This may explain the lower prevalence of infestation during the hottest summer months. This resembles the highest prevalence in ground-dwelling rodents occurring in Germany from May to July (MatuschKa et al. 1990) and in the UK in August (Cull et al. 2017 and other references therein). Abundance of questing ticks also differs with landscape features and plant communities (Schwarz et al. 2009, PerEz et al. 2016). This point has to be taken into account for future investigations and comparisons between sites.

Numerous factors might influence the observed pattern of ticks on the dormouse body. Their preference for the head region and especially the ears (Fig. 4) is in line with observations in most other mammals (e.g. RANDOLPH 1975, KifFNER et al. 2011, FiETZ et al. 2016). It may result from different grooming behaviours of the hosts (RANDOLPH 1975).

Due to the preliminary nature of this paper and the small sample size, we were not able to address relevant topics, such as the influence of sex, size, weight or age of the hosts on the prevalence of their ticks (Soliman et al. 2001, Morand et al. 2004, Christe et al. 2007, Harrison et al. 2010). These parameters will be addressed when the sample size allows for statistical analysis.

\section{SOUHRN}

Na sedmi místech v Německu jsme v květnu až září 2017 odebírali klíš'ata z plšíků lískových (Muscardinus avellanarius). Z celkového počtu 221 vyšetřených plšíků jich bylo $19 \%$ napadeno klišt’aty, ale míra nákazy se mezi lokalitami a měsíci výrazně lišila. Nejvyšší prevalence klíšt’at na jednom místě byla zaznamenána v záŕí $(55 \%)$, zatímco nejnižší v červenci $(0 \%)$. V červnu se prevalence mezi jednotlivými lokalitami pohybovala v rozmezí 0-47 \%. Plšíci byli nakaženi nejčastěji jedním klíštětem, maximální počet klíštat zjištěných u jednoho zvířete byl 12. Všechna klišs’ata byla nalezena na hlavě plšíků, kde nejčastějšími místy přisátí byly uši, čenich a oblasti kolem očí.

\section{Acknow ledgements}

We thank D. RichteR and R. JUŠKAITIS for very helpful comments on the original manuscript and P. MoRRIS for language editing. 


\section{REFERENCES}

Alkishe A. A., Peterson A. T. \& Samy A. M., 2017: Climate change influences on the potential geographic distribution of the disease vector tick Ixodes ricinus. Public Library of Science One, 12(12): 1-14.

Bright P. W. \& MorRis P. A., 1991: Ranging and nesting behaviour of the dormouse, Muscardinus avellanarius, in diverse low-growing woodland. Journal of Zoology, London, 224: 177-190.

Bright P. W. \& Morris P. A., 1992: Ranging and nesting behaviour of the dormouse Muscardinus avellanarius, in coppice-with-standards woodland. Journal of Zoology, London, 226: 589-600.

BüChNER S., LANG J. \& Jokisch S., 2010: Monitoring der Haselmaus Muscardinus avellanarius in Hessen im Rahmen der Berichtspflicht zur FFH-Richtlinie. Natur und Landschaft, 85: 334-339.

Christe P., Glaizot O., Evanno G., Bruyndonckx N., Devevey G., Yannic G., Patthey P., Maeder A., Vogel P. \& Arlettaz R., 2007: Host sex and ectoparasites choice: preference for, and higher survival on female hosts. Journal of Animal Ecology, 76: 703-710.

Cull B., Vaux A. G. C., Ottowell L. J., Gillingham E. L. \& Medlock J. M., 2017: Tick infestation of small mammals in an English woodland. Journal of Vector Ecology, 42: 74-83.

Fietz J., Langer F., Havenstein N., Matuschia F.-R. \& Richter D., 2016: The vector tick Ixodes ricinus feeding on an arboreal rodent-the edible dormouse Glis glis. Parasitology Research, 115: 1435-1442.

Harrison A., Scantlebury M. \& Montgomery W. I., 2010: Body mass and sex-biased parasitism in wood mice Apodemus sylvaticus. Oikos, 119: 1099-1104.

JušKaItis R., 2014: The Common Dormouse Muscardinus avellanarius: Ecology, Population Structure and Dynamics. Second Edition. Nature Research Centre Publishers, Vilnius, 195 pp.

JušKaitis R. \& BÜchner S., 2013: The Hazel Dormouse. NBB English Edition, Westarp Wissenschaften, Hohenwarsleben, 173 pp.

Khokhlova I. S., Krasnov B. R., Kam M., Burdelova N. I. \& Degen A. A., 2006: Energy cost of ectoparasitism: the flea Xenopsylla ramesis on the desert gerbil Gerbillus dasyurus. Journal of Zoology, London, 258: 349-354.

Kiffner C., Lödige C., Alings M., Vor T. \& RÜHe F., 2011: Attachment site selection of ticks on roe deer, Capreolus capreolus. Experimental and Applied Acarology, 53: 79-94.

Lang J., Leonhardt I., Beer S., Bräsel N., Lanz J. D. \& Schmittfull D., 2018: What Muscardinus avellanarius like but consultants don't: performance of nest boxes vs. nest tubes for translocations (Rodentia: Gliridae). Lynx, n. s., 49: 43-48.

Lehmann T., 1992: Ectoparasite impacts on Gerbillus andersoni allenbyi under natural conditions. Parasitology, 104: 479-488.

Lehmann T., 1993: Ectoparasites: Direct impact on host fitness. Parasitology Today, 9: 8-13.

Matuschia F.-R., Lange R., Spielman A., Richter D. \& Fischer P., 1990: Subadult Ixodes ricinus (Acari: Ixodidae) on rodents in Berlin, West Germany. Journal of Medical Entomology, 27: 385-390.

Matuschka F.-R., Allgöwer R., Spielman A. \& Richter D., 1999: Characteristics of garden dormice that contribute to their capacity as reservoirs for Lyme disease spirochetes. Applied and Environmental Microbiology, 65: 707-711.

Morand S., Goüy De Belloce J., Stanko M. \& Miklisová D., 2004: Is sex-biased ectoparasitism related to sexual size dimorphism in small mammals of Central Europe? Parasitology, 129: 505-510.

Neunaus P., 2003: Parasite removal and its impact on litter size and body condition in Columbian ground squirrels (Spermophilus columbianus). Proceedings of the Royal Society B, 270: 213-215.

PéreZ D., KNeUbÜHLER Y., RaIs O. \& Gern L., 2012: Seasonality of Ixodes ricinus ticks on vegetation and on rodents and Borrelia burgdorferi sensu lato genospecies diversity in two Lyme borreliosis-endemic areas in Switzerland. Vector Borne and Zoonotic Diseases, 12(8): 633-644.

Perez G., Bastian S., Agoulon A., Bouju A., Durand A., Faille F., Lebert I., Rantier Y., Plantard O. $\&$ Butet A., 2016: Effect of landscape features on the relationship between Ixodes ricinus ticks and their small mammal hosts. Parasites \& Vectors, 9: 20.

Pfäffle M., Petney T., Elgas M., Skubulla J. \& Taraschewski H., 2009: Tick-induced blood loss leads to regenerative anaemia in the European hedgehog (Erinaceus europaeus). Parasitology, 136: 443-452. 
Price P. W., 1980: Evolutionary Biology of Parasites. Princeton University Press, Princeton, NJ, 256 pp. RANDOLPH S. E., 1975: Patterns of distribution of the tick Ixodes trianguliceps Birula on its hosts. Journal of Animal Ecology, 44: 451-474.

RANDOLPH S. E. \& STOREY K., 1999: Impact of microclimate on immature tick-rodent host interactions (Acari: Ixodidae): Implications for parasite transmission. Journal of Medical Entomology, 36:741-748.

Richter D., Schlee D., Allgöwer R. \& Matuschka F.-R., 2004: Relationships of a novel Lyme disease spirochete, Borrelia spielmani, sp. nov. with its hosts in Central Europe. Applied and Environmental Microbiology, 70: 6414-6419.

Richter D. \& MatuschKa F.-R., 2012: Differential contribution of various dormice to the natural transmission cycle of Lyme disease spirochetes in Central Europe. Peckiana, 8: 235-244.

Schwarz A., Maier W. A., Kistemann T. \& Kampen H., 2009: Analysis of the distribution of the tick Ixodes ricinus L. (Acari: Ixodidae) in a nature reserve of western Germany using Geographic Information Systems. International Journal of Hygiene and Environmental Health, 212: 87-96.

Soliman S., Marzouk A. S., Main A. J. \& Montasser A. A., 2001: Effect of sex, size, and age of commensal rat hosts on the infestation parameters of their ectoparasites in a rural area of Egypt. Journal of Parasitology, 87: 1308-1316.

VAN VUREN D., 1996: Ectoparasites, fitness, and social behaviour of yellow-bellied marmots. Ethology, 102: 686-694. 